Article

\title{
Four New 2-(2-Phenylethyl)chromone Derivatives from Chinese Agarwood Produced via the Whole-Tree Agarwood-Inducing Technique
}

\author{
Yang-Yang Liu ${ }^{1,2}$, De-Li Chen ${ }^{2}$, Jian-He Wei ${ }^{1,2, *}$, Jian Feng ${ }^{2}$, Zheng Zhang ${ }^{1,2}$, Yun Yang ${ }^{1,2}$ \\ and Wei Zheng ${ }^{2}$ \\ 1 Institute of Medicinal Plant Development (National Engineering Laboratory for Breeding of Endangered \\ Medicinal Materials), Chinese Academy of Medical Sciences \& Peking Union Medical College, \\ Beijing 100193, China; yyliu@implad.ac.cn (Y.-Y.L.); 18911570328@126.com (Z.Z.); \\ yangyun43@aliyun.com (Y.Y.) \\ 2 Hainan Branch of Institute of Medicinal Plant Development, Chinese Academy of Medicinal Sciences \& \\ Peking Union Medical College (Hainan Provincial Key Laboratory of Resources Conservation and \\ Development of Southern Medicine), Haikou 570311, China; chendeli9999@163.com (D.-L.C.); \\ jianfenghn@126.com (J.F.); wee000123@163.com (W.Z.) \\ * Correspondence: wjianh@263.net; Tel.: +86-10-62818841
}

Academic Editor: Thomas J. Schmidt

Received: 26 August 2016; Accepted: 22 October 2016; Published: 27 October 2016

\begin{abstract}
Four new 2-(2-phenylethyl)chromone derivatives (1-4) were isolated from the EtOH extract of Chinese agarwood produced via the whole-tree agarwood-inducing technique, coming from Aquilaria sinensis (Lour.) Spreng. (Thymelaeaceae). Their structures were elucidated by extensive spectroscopic methods, such as UV, IR, MS, 1D as well as 2D NMR. All of the isolates were then assessed for their anti-inflammatory activities on lipopolysaccharide (LPS)-induced nitric oxide (NO) production in RAW 264.7. Compound 1 exhibited significant inhibitory activity with an $\mathrm{IC}_{50}$ value of $4.6 \mu \mathrm{M}$.
\end{abstract}

Keywords: Chinese agarwood; 2-(2-phenylethyl)chromone derivatives; Aquilaria sinensis; whole-tree agarwood-inducing technique; anti-inflammatory

\section{Introduction}

Agarwood or eaglewood (also known as chen xiang in China, agar in India, oud in the Middle East, gaharu in the South East Asia and jinkoh in Japan) is the resinous wood of the Aquilaria spp. trees. It is actually an angiosperm existing in the Thymelaeaceae family [1]. This cherished fragrant type of wood has for long been used as an incense, especially among the Buddhist, Hindu as well as for Islamic ceremonies [2]. Moreover, agarwood also plays a fundamental role in the traditional Chinese medicine due to of its medicinal value. It is considered to have sedative as well as carminative properties. Again, it has been used in relieving gastric problems, coughs, anti-emetic effects, rheumatism as well as high fever [2,3]. In China, the main source of agarwood is the Aquilaria sinensis, a large evergreen tree, distributed in the Hainan, Guangdong, Guangxi, and Fujian provinces.

Agarwood mainly forms in the wood tissues of wild or cultivated Aquilaria trees after wounding. This can mainly be caused by external factors like physical injury, insect gnawing, or microbial infection [4]. Usually, the tree takes several years to form the agarwood around the tissues wound. A lot of factors have led to the depletion of wild Aquilaria trees. These include agarwood's immense value and rarity, indiscriminate cutting of trees, as well as over-harvesting. Our laboratory has therefore patented an effective method, which is the whole-tree agarwood inducing technique (Agar-Wit) $[2,5,6]$, in China. In fact, it is currently being filed for international patent. In this technique, there were 
small holes deep into the xylem drilled into the main trunk of Aquilaira tree by use of an electric drill. The agarwood inducer was then slowly injected into the xylem tissues through a simple and cheap transfusion set to induce formation of high-quality agarwood in a shorter time compared to other conventional techniques.

Previous phytochemical investigations on the Chinese agarwood revealed that chromone derivatives are among the main chemical components [7]. Some of these chemical components were also found to possess significant anti-inflammatory activity [8]. Nonetheless, chemical constituents of the Chinese agarwood were induced by the Agar-Wit technique from A. sinensis to contain just few reports [2]. As the inventor, it necessitated an investigation of the characteristic chromones of this agarwood. Our results gave out four new 2-(2-phenylethyl)chromone derivatives (1-4) (Figure 1) from the ethanol extract. This was also shown to be a moderate anti-inflammation activity. In this paper, the isolation and structural elucidation of these new compounds are described, merged with their inhibitory activities against LPS-induced NO production in macrophages.<smiles>COc1ccc(CCc2cc(=O)c3c(O)cc(OC)cc3o2)cc1</smiles>

1<smiles>COc1ccc(CCc2cc(=O)c3c(o2)[C@H](O)[C@H](O)[C@H]2O[C@@H]32)cc1O</smiles>

3<smiles>COc1cc(O)c2oc(CCc3ccccc3)cc(=O)c2c1O</smiles>
2<smiles>COc1ccc2oc(CCc3ccc(O)c(O)c3O)cc(=O)c2c1</smiles>

4

Figure 1. Structures of compounds $\mathbf{1 - 4}$.

\section{Results and Discussion}

Compound 1 was isolated as pale yellow amorphous powder. Its molecular formula was determined to be $\mathrm{C}_{19} \mathrm{H}_{18} \mathrm{O}_{5}$ from the molecular ion peak at $m / z 349.1023[\mathrm{M}+\mathrm{Na}]^{+}$(calcd for $\mathrm{C}_{19} \mathrm{H}_{18} \mathrm{O}_{5} \mathrm{Na}$. 349.1052) from the HR-ESI-MS. Again, the IR spectrum indicated the presence of hydroxyl group $\left(3415 \mathrm{~cm}^{-1}\right)$ and $\alpha, \beta$-unsaturated carbonyl group $\left(1620 \mathrm{~cm}^{-1}\right)$. The ${ }^{1} \mathrm{H}-\mathrm{NMR}$ spectroscopic data (Table 1) of $\mathbf{1}$ depicted the presence of two methoxyl groups at $\delta_{\mathrm{H}} 3.90$ and 3.88 (each $3 \mathrm{H}, \mathrm{s}$ ), one hydroxyl signal at $\delta_{\mathrm{H}} 12.80$, as well as two aromatic protons at $\delta_{\mathrm{H}} 6.37$ and 6.49 . These were assigned to $\mathrm{H}-6$ and $\mathrm{H}-8$ respectively. In addition, a set of typical $\mathrm{A}_{2} \mathrm{~B}_{2}$ coupling systems at $\delta_{\mathrm{H}} 7.84(2 \mathrm{H}, \mathrm{d}, 9.0 \mathrm{~Hz}) ; \delta_{\mathrm{C}} 128.9$, and $\delta_{\mathrm{H}} 7.02 ; \delta_{\mathrm{C}} 114.8(2 \mathrm{H}, \mathrm{d}, 9.0 \mathrm{~Hz})$, as well as four methylene protons at $\delta_{\mathrm{H}} 2.35\left(2 \mathrm{H}, \mathrm{d}, 7.2 \mathrm{~Hz}, \mathrm{H}-7^{\prime}\right)$ and $\delta_{\mathrm{H}} 2.80\left(2 \mathrm{H}, \mathrm{d}, 7.2 \mathrm{~Hz}, \mathrm{H}-8^{\prime}\right)$ were also observed from HSQC spectrum. Analysis of the ${ }^{13} \mathrm{C}-\mathrm{NMR}$ spectroscopic data (Table 2, see Supplementary Materials) showed that 1 had two methylene groups at $\delta_{C} 33.0$ and 36.5, an $\alpha, \beta$-unsaturated ketone at $\delta_{C} 108.0,169.8$ and 182.7, two methoxyl groups at $\delta_{C} 55.7$ and 55.9, as well as other two aromatic rings in an $A B$ and $A_{2} B_{2}$ patterns. Considering these, which suggested that compound 1 was a 2-(2-phenylethyl)chromone derivative with one hydroxyl as well as two methoxyl groups. Based on the HMBC spectroscopic 
experiment (Figure 2), the hydroxyl group was located at C-5 since the hydroxyl proton $\left(\delta_{\mathrm{H}} 12.80\right)$ correlated with the carbon at C-5 $\left(\delta_{C} 149.8\right), C-10\left(\delta_{C} 110.8\right)$ as well as C-6 $\left(\delta_{C} 98.3\right)$. The methoxyl groups were attached to $C-7$ and $C-44^{\prime}$, respectively. This is also on the basis of correlations from $\delta_{\mathrm{H}} 3.90$ to the aromatic carbon at $\delta_{\mathrm{C}} 165.9$, the $\delta_{\mathrm{H}} 3.88$ to the carbon at $\delta_{\mathrm{C}} 157.0$. Therefore, compound 1 was realised to be 5-hydroxyl-7-methoxy-2-[2-(4'-methoxyphenyl)ethyl]chromone.

Table 1. ${ }^{1} \mathrm{H}-\mathrm{NMR}(600 \mathrm{MHz})$ assignments of compounds 1-4 $\left(\mathrm{CDCl}_{3}\right)$.

\begin{tabular}{ccccc}
\hline \multirow{2}{*}{ Attribution } & \multicolumn{4}{c}{$\delta_{\mathbf{H}}(\boldsymbol{J}$ in $\mathbf{H z})$} \\
\cline { 2 - 5 } & $\mathbf{1}$ & $\mathbf{2}$ & $\mathbf{3}$ & $\mathbf{4}$ \\
\hline 3 & $6.59, \mathrm{~s}$ & $6.04, \mathrm{~s}$ & $6.13, \mathrm{~s}$ & $6.13, \mathrm{~s}$ \\
5 & - & - & $5.02, \mathrm{~d}(4.8)$ & $7.55, \mathrm{~d}(3.0)$ \\
6 & $6.37, \mathrm{~d}(2.4)$ & - & $4.32, \mathrm{dd}(10.2,4.8)$ & - \\
7 & - & $6.86, \mathrm{~s}$ & $4.08, \mathrm{dd}(10.2,7.2)$ & $7.24, \mathrm{dd}(9.0,3.0)$ \\
8 & $6.49, \mathrm{~d}(2.4)$ & - & $4.94, \mathrm{~d}(7.2)$ & $7.37, \mathrm{~d},(9.0)$ \\
$2^{\prime}$ & $7.84, \mathrm{~d}(9.0)$ & $7.29, \mathrm{~d}(7.2)$ & $6.74, \mathrm{~d}(1.8)$ & - \\
$3^{\prime}$ & $7.02, \mathrm{~d}(9.0)$ & $7.21, \mathrm{t}(7.2)$ & - & - \\
$4^{\prime}$ & - & $7.27, \mathrm{~m}$ & - & - \\
$5^{\prime}$ & $7.02, \mathrm{~d}(9.0)$ & $7.21, \mathrm{t}(7.2)$ & $6.76, \mathrm{~d}(8.4)$ & $6.75, \mathrm{~d}(8.4)$ \\
$6^{\prime}$ & $7.84, \mathrm{~d}(9.0)$ & $7.29, \mathrm{~d}(7.2)$ & $6.62, \mathrm{dd}(8.4,1.8)$ & $7.05, \mathrm{~d}(8.4)$ \\
$7^{\prime}$ & $2.35, \mathrm{t}(7.2)$ & $3.05, \mathrm{~m}$ & $2.98, \mathrm{t}(7.2)$ & $2.99, \mathrm{t}(7.2)$ \\
$8^{\prime}$ & $2.80, \mathrm{t}(7.2)$ & $2.95, \mathrm{~m}$ & $2.90, \mathrm{t}(7.2)$ & $2.89, \mathrm{t}(7.2)$ \\
$6-\mathrm{OCH}_{3}$ & - & $3.93, \mathrm{~s}$ & - & $3.88, \mathrm{~s}$ \\
$7-\mathrm{OCH}_{3}$ & $3.90, \mathrm{~s}$ & - & - & - \\
$4^{\prime}-\mathrm{OCH} \mathrm{H}_{3}$ & $3.88, \mathrm{~s}$ & - & $3.90, \mathrm{~s}$ & - \\
$5-\mathrm{OH}$ & $12.80, \mathrm{~s}$ & $12.66, \mathrm{~s}$ & - & - \\
\hline
\end{tabular}

Table 2. ${ }^{13} \mathrm{C}-\mathrm{NMR}(150 \mathrm{MHz})$ assignments of compounds 1-4 $\left(\mathrm{CDCl}_{3}\right)$.

\begin{tabular}{ccccc}
\hline \multirow{2}{*}{ Attribution } & \multicolumn{3}{c}{$\boldsymbol{\delta}_{\mathbf{C}}$} & $\mathbf{4}$ \\
\cline { 2 - 5 } & $\mathbf{1}$ & $\mathbf{2}$ & $\mathbf{3}$ & 168.6 \\
\hline 2 & 169.8 & 170.3 & 169.9 & 109.7 \\
3 & 108.0 & 108.1 & 114.1 & 178.5 \\
4 & 182.7 & 184.2 & 179.8 & 105.0 \\
5 & 149.8 & 150.7 & 56.5 & 157.0 \\
6 & 98.3 & 143.5 & 61.9 & 123.8 \\
7 & 165.9 & 105.9 & 69.1 & 119.6 \\
8 & 92.9 & 151.2 & 70.8 & 151.5 \\
9 & 150.6 & 149.8 & 157.0 & 131.9 \\
10 & 110.8 & 111.1 & 122.0 & 151.2 \\
$1^{\prime}$ & 140.0 & 139.9 & 132.3 & 140.1 \\
$2^{\prime}$ & 128.9 & 128.9 & 114.5 & 154.5 \\
$3^{\prime}$ & 114.8 & 128.4 & 145.6 & 115.7 \\
$4^{\prime}$ & 157.0 & 123.3 & 146.0 & 129.6 \\
$5^{\prime}$ & 114.8 & 128.4 & 111.1 & 32.4 \\
$6^{\prime}$ & 128.9 & 128.9 & 119.8 & 36.6 \\
$7^{\prime}$ & 33.0 & 33.3 & 32.4 & 56.1 \\
$8^{\prime}$ & 36.5 & 36.4 & 35.6 & - \\
$6^{\prime}-\mathrm{OCH}_{3}$ & - & 57.3 & - & - \\
$7-\mathrm{OCH}_{3}$ & 55.9 & - & & \\
$4^{\prime}-\mathrm{OCH}_{3}$ & 55.7 & - & 56.2 & \\
\hline
\end{tabular}



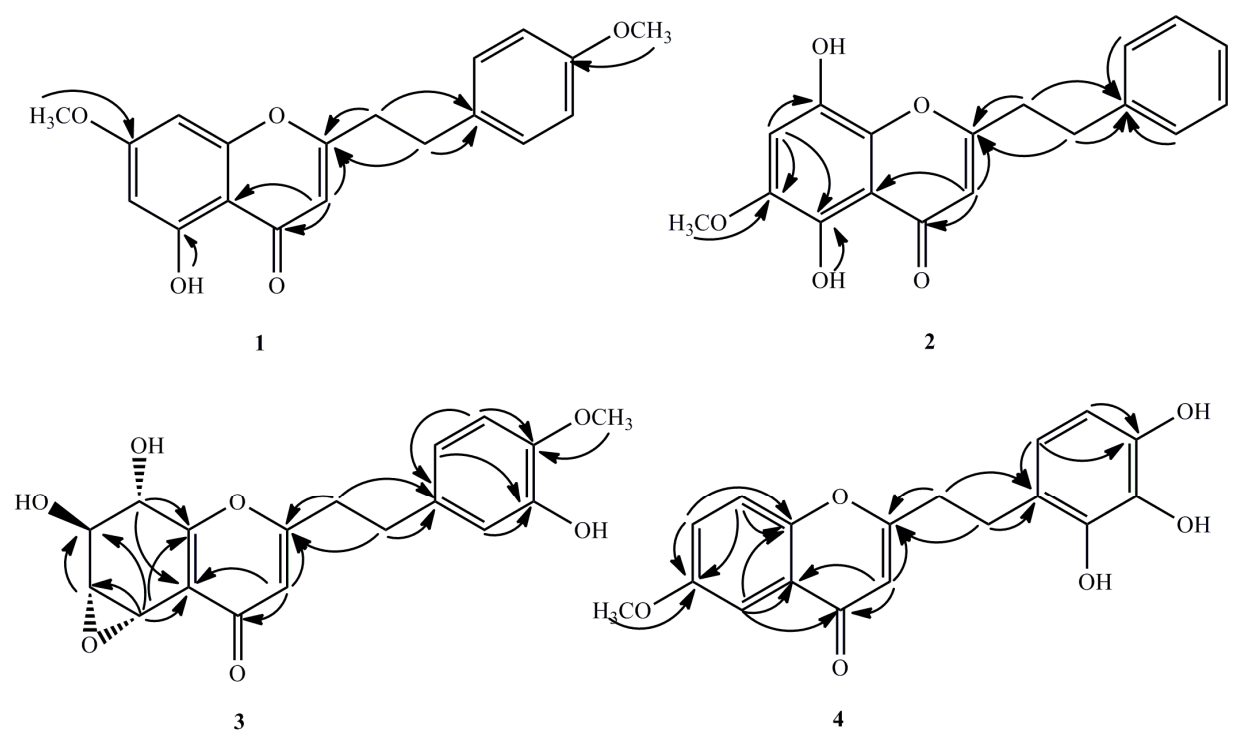

Figure 2. Key HMBC correlations of compounds 1-4.

Compound 2 was obtained as yellow amorphous powder. The molecular formula established as $\mathrm{C}_{18} \mathrm{H}_{16} \mathrm{O}_{5}$ by its HR-ESI-MS at $m / z$ 335.0902 [M + Na] $]^{+}$(calcd for $\mathrm{C}_{18} \mathrm{H}_{16} \mathrm{O}_{5} \mathrm{Na}$, 335.0895). The IR spectrum also demonstrated absorption bands of hydroxyl group $\left(3424 \mathrm{~cm}^{-1}\right)$ as well as aromatic ring $\left(1610,1512\right.$ and $\left.1455 \mathrm{~cm}^{-1}\right)$. The UV spectrum further depicted the presence of an $\alpha, \beta$-unsaturated carbonyl group out of the distinct absorption maximum at 242 and $322 \mathrm{~nm}$. Moreover, the ${ }^{1} \mathrm{H}-\mathrm{NMR}$ spectrum (Table 1) also outlaid the presence of one methoxyl group at $\delta_{\mathrm{H}} 3.93(3 \mathrm{H}, \mathrm{s})$, one hydroxyl signal at $\delta_{\mathrm{H}}$ 12.66, as well as one singlet aromatic protons at $\delta_{\mathrm{H}} 6.86$, and an $\mathrm{A}_{2} \mathrm{~B}_{2} \mathrm{X}$ coupling system at $\delta_{\mathrm{H}} 7.21(2 \mathrm{H}, \mathrm{t}, 7.2 \mathrm{~Hz}), \delta_{\mathrm{C}} 128.4, \delta_{\mathrm{H}} 7.29(2 \mathrm{H}, \mathrm{d}, 7.2 \mathrm{~Hz}), \delta_{\mathrm{C}} 128.9$, and $\delta_{\mathrm{H}} 7.27(\mathrm{~m}), \delta_{\mathrm{C}} 123.3$. The ${ }^{13} \mathrm{C}-\mathrm{NMR}$ spectrum (Table 2, see Supplementary Materials) of 2 illustrated signals for two methylene groups at $\delta_{C} 33.3$ and 36.4 , a trisubstituted double bond at $\delta_{C} 108.1$ and 170.3, one methoxyl groups at $\delta_{C} 57.3$, and a carbonyl group at $\delta_{C}$ 184.2. Basing on these findings, we realized that compound 2 was a 2-(2-phenylethyl)chromone derivative with two hydroxyl and one methoxyl groups which was then affirmed by the HMBC spectrum (Figure 2). In the HMBC spectrum, the correlations from methoxy signal $\left(\delta_{\mathrm{H}} 3.93\right)$ to the carbon at $\delta_{\mathrm{C}} 143.5(\mathrm{C}-6)$ and $\delta_{\mathrm{H}} 6.86(\mathrm{~s}, \mathrm{H}-7)$ to $\delta_{\mathrm{C}} 143.5(\mathrm{C}-6)$ indicated that the methoxy $\left(\delta_{\mathrm{H}} 3.93\right)$ was located at C-6. Moreover, one hydroxyl group was linked to C-5 on the basis of the correlations between $5-\mathrm{OH}\left(\delta_{\mathrm{H}} 12.66\right)$ and $\mathrm{C}-5\left(\delta_{\mathrm{C}} 150.7\right)$. The other hydroxyl group was located at C-8, due to the downfield-shifted carbon at C-8 $\left(\delta_{C} 151.2\right)$ as well as the molecular formula above. Thus, the structure of compound 2 was assigned to be 5,8-dihydroxy-6-methoxy-2-(2-phenylethyl)chromone.

Compound 3 was obtained as a pale brown amorphous powder. The molecular formula established as $\mathrm{C}_{18} \mathrm{H}_{18} \mathrm{O}_{7}$ by its HR-ESI-MS at $m / z 371.1103[\mathrm{M}+\mathrm{Na}]^{+}$(calcd for $\mathrm{C}_{18} \mathrm{H}_{18} \mathrm{O}_{7} \mathrm{Na}$, 371.1107) the IR spectrum showed absorption bands of hydroxyl groups $\left(3410,3010 \mathrm{~cm}^{-1}\right)$ and aromatic ring $\left(1610,1500\right.$ and $\left.1425 \mathrm{~cm}^{-1}\right)$. The ${ }^{1} \mathrm{H}-\mathrm{NMR}$ spectrum (Table 1) showed that the presence of one methoxyl group at $\delta_{\mathrm{H}} 3.90(3 \mathrm{H}, \mathrm{s})$, two methylene groups at $\delta_{\mathrm{H}} 2.90,2.98($ each $2 \mathrm{H}, \mathrm{t}, \mathrm{J}=7.2$ $\mathrm{Hz})$, four oxygenated methine protons at $\delta_{\mathrm{H}} 4.08(\mathrm{dd}, J=10.2,7.2 \mathrm{~Hz}), 4.32(\mathrm{dd}, J=10.2,4.8 \mathrm{~Hz})$, $4.94(\mathrm{~d}, J=7.2 \mathrm{~Hz}), 5.02(\mathrm{~d}, J=4.8 \mathrm{~Hz})$, and four aromatic protons at $6.62(\mathrm{dd}, J=8.4,1.8 \mathrm{~Hz})$, $6.76(\mathrm{~d}, J=8.4 \mathrm{~Hz}), 6.74(\mathrm{~d}, J=1.8 \mathrm{~Hz}), 6.13(\mathrm{~s})$. The ${ }^{13} \mathrm{C}-\mathrm{NMR}$ spectrum (Table 2, see supporting information) displayed 18 carbon signals of two methylene groups $\left(\delta_{C} 32.4\right.$ and 35.6), a phenyl group $\left(\delta_{C} 119.8,111.1,146.0,145.6,114.5\right.$, and 132.3$)$, a conjugated moiety $\left(\delta_{C} 114.1,122.0,157.0,169.9,179.8\right)$, four oxygenated methine carbons $\left(\delta_{C} 56.5,61.9,69.1\right.$, and 70.8$)$, and one methoxy carbon $\left(\delta_{C} 56.2\right)$. From the ${ }^{1} \mathrm{H}-\mathrm{NMR},{ }^{1} \mathrm{H}-{ }^{1} \mathrm{H}$ COSY, and HSQC spectra, these four carbons were concluded to form a series of consecutive methines $\left(\delta_{C} 56.5, \delta_{\mathrm{H}} 5.02 ; \delta_{C} 61.9, \delta_{\mathrm{H}} 4.32 ; \delta_{C} 69.1, \delta_{\mathrm{H}} 4.08 ; \delta_{C} 70.8, \delta_{\mathrm{H}} 4.94\right)$. In the HMBC spectrum (Figure 2), the methine proton at $\delta_{\mathrm{H}} 5.02$, which was located at one end of 
the consecutive methine, showed correlation peaks with the two olefinic carbons $\left[\delta_{C} 122.0(C-10)\right.$ and 157.0 (C-9)], whereas the methine proton at $\delta_{\mathrm{H}} 4.94$, which was located at the other end of the methine, correlated with the latter two olefinic carbons $\left(\delta_{C} 122.0\right.$ and 157.0). These correlations indicate that these methines form a part of a tetrasubstituted tetrahydrochromone moiety. The HMBC correlations from $\delta_{\mathrm{H}} 3.90$ and 6.76 to $\delta_{\mathrm{C}} 146.0$ indicated that the methoxy located at $\mathrm{C}-4^{\prime}$. The hydroxy linked at $C-3^{\prime}\left(\delta_{\mathrm{C}} 145.6\right)$ because the $\delta_{\mathrm{H}} 6.74\left(\mathrm{H}-2^{\prime}\right)$ and $\delta_{\mathrm{H}} 6.62\left(\mathrm{H}-6^{\prime}\right)$ correlated with the carbon at C-3'. On the basis of ${ }^{1} \mathrm{H}-\mathrm{NMR}$ and ${ }^{13} \mathrm{C}-\mathrm{NMR}$ data, the structure of compound 3 is very similar to a reported compound named rel-(1aR,2R,3R,7bS)-1a,2,3,7b-Tetrahydro-2,3-dihydroxy-5-[2-(3-hydroxy-4-methoxy phenyl)ethyl]-7H-oxireno[f][1] benzopyran-7-one [9], except for two strongly downfield-shifted signals at $\delta_{C} 61.9$ (C-6) and 56.5 (C-5) compared with the known one at $\delta_{C} 54.8$ (C-6) and 49.5 (C-5), due to the relative configuration of epoxy group in this region, which was further confirmed by the NOESY correlations. In the NOESY spectrum, the correlations between H-5, H-6 and H-8 indicated the epoxy group was $\alpha$-oriented. The $J^{3}$-coupling constant $(10.2 \mathrm{~Hz})$ also supported an antiperiplanar relationship between H-6 and H-7. Therefore, the structure of compound 3 was assigned to be $5 \alpha, 6 \alpha$-epoxy-7 $\beta, 8 \alpha, 3^{\prime}$-trihydroxy-4'-methoxy-2-(2-phenylethyl)chromone.

Compound 4 was obtained as a pale brown amorphous powder. The molecular formula of compound 4 was determined to be $\mathrm{C}_{18} \mathrm{H}_{16} \mathrm{O}_{6}$ by HR-ESI-MS $\left(\mathrm{m} / z 351.0821[\mathrm{M}+\mathrm{Na}]^{+}\right.$, calc. for $\mathrm{C}_{18} \mathrm{H}_{16} \mathrm{O}_{6} \mathrm{Na}$, 351.0845). The IR spectrum exhibited the presence of hydroxy group(s) at $3340 \mathrm{~cm}^{-1}$. The ${ }^{1} \mathrm{H}-\mathrm{NMR}$ spectrum (Table 1) showed the presence of one methoxyl group at $\delta_{\mathrm{H}} 3.88(3 \mathrm{H}, \mathrm{s})$, two methylene groups at $\delta_{\mathrm{H}} 2.99,2.89$ (each $2 \mathrm{H}, \mathrm{t}, J=7.2 \mathrm{~Hz}$ ), six aromatic protons at $\delta_{\mathrm{H}} 6.13(\mathrm{~s}), 7.55$ $(\mathrm{d}, J=3.0 \mathrm{~Hz}), 7.24,(\mathrm{dd}, J=9.0,3.0 \mathrm{~Hz}), 7.37(\mathrm{~d}, J=9.0 \mathrm{~Hz}), 6.75(\mathrm{~d}, J=8.4 \mathrm{~Hz})$ and $7.05(\mathrm{~d}, J=8.4 \mathrm{~Hz})$. The ${ }^{13} \mathrm{C}$-NMR spectrum (Table 2, see supporting information) of 4 showed 18 carbon signals including one methoxy at $\delta_{C} 56.1$, two methylene groups at $\delta_{C} 32.4$ and 36.6 , six methine at $\delta_{C} 109.7,105.0,123.8$, 119.6, 115.7 and 129.6, and nine quaternary carbons at $\delta_{C} 168.6,178.5,157.0,151.5,124.4,131.9,151.2$, 140.1 and 154.5. Based on the combined analyses of the IR, ${ }^{1} \mathrm{H}-\mathrm{NMR}$, and ${ }^{13} \mathrm{C}-\mathrm{NMR}$ spectroscopic data, compound 4 was another 2-(2-phenylethyl)chromone derivative with one methoxyl group and three hydroxyl groups, which was further confirmed by HMBC correlations (Figure 2). In the HMBC spectrum, the correlations from the methoxy $\left(\delta_{\mathrm{H}} 3.88\right)$ and $\mathrm{H}-7\left(\delta_{\mathrm{H}} 7.24\right)$ to the carbon at $\delta_{\mathrm{C}} 157.0$, indicated that the methoxy $\left(\delta_{\mathrm{H}} 3.88\right)$ was located on C-6 $\left(\delta_{C} 157.0\right)$, in which the integration value of H-7 was enhanced when the methoxy protons at $\delta_{\mathrm{H}} 3.88$ was irradiated. The positions of the hydroxyl groups were attached to $C-2^{\prime} / 3^{\prime} / 4^{\prime}$, respectively on the basis of the downfield carbons at $\delta_{\mathrm{C}} 151.2$ $\left(\mathrm{C}-2^{\prime}\right), 140.1\left(\mathrm{C}-3^{\prime}\right), 154.5\left(\mathrm{C}-4^{\prime}\right)$, together with the molecular formula above. Thus, the structure of 4 was identified as 6-methoxy-2-[2-(2',3',4'-trihydroxy)phenyl)ethyl]chromone.

Considering this medicinal herb as a therapeutical agent of analgesics and asthmatic, the isolated compounds $\mathbf{1 - 4}$ were studied for their anti-inflammatory activities on lipopolysaccharide (LPS)-induced nitric oxide (NO) production in RAW 264.7. The results showed that compound 1 showed significant inhibitory activities with $\mathrm{IC}_{50}$ value of $4.6 \mu \mathrm{M}$ and compound 3 displayed moderate activity with $\mathrm{IC}_{50}$ value of $84 \mu \mathrm{M}$ comparing of the positive drug control group aminoguanidine with $\mathrm{IC}_{50}$ value of $1.8 \mu \mathrm{M}$, while compounds 2 and 4 were inactive (Table 3).

Table 3. Inhibitory activity of compounds on lipopolysaccharide (LPS)-induced nitric oxide (NO) production in RAW 264.7 macrophages.

\begin{tabular}{ccc}
\cline { 2 - 2 } Compounds & IC $_{\mathbf{5 0}}{ }^{\mathbf{a}}(\boldsymbol{\mu M})$ \\
\hline $\mathbf{1}$ & $4.6 \pm 0.1$ \\
$\mathbf{2}$ & $\mathrm{NA}$ \\
$\mathbf{3}$ & $84 \pm 2$ \\
$\mathbf{4}$ & $\mathrm{NA}$ \\
a Value present mean $\pm \mathrm{SD}$ of triplicate experiments. ${ }^{\mathrm{b}}$ Positive control substance. NA: No Activity. &
\end{tabular}




\section{Materials and Methods}

\subsection{General Experimental Procedures}

1D and 2D NMR spectra were obtained with a Bruker AV III 600NMR spectrometer (Bruker, Billerica, German) using TMS as the internal standard. HRESIMS spectra were performed on a LTQ-Obitrap XL spectrometer (Thermo Fisher Scientific, Boston, MA, USA). Optical rotations were obtained on a Perkin-Elmer 341 digital polarimeter (PerkinElmer, Norwalk, CT, USA). UV and IR spectra were recorded on Shimadzu UV2550 and FTIR-8400S spectrometers (Shimadzu, Kyoto, Japan), respectively. Semi-preparative LC was performed on a Lumtech K-1001 analytic LC (Beijing, China) which is equipped with two pumps of K-501, a UV detector of K-2600, as well as an YMC Pack C18 column (250 mm $\times 10 \mathrm{~mm}$, i.d., $5 \mu \mathrm{M}$, YMC Co. Ltd., Kyoto, Japan) eluted with $\mathrm{CH}_{3} \mathrm{CN}-\mathrm{H}_{2} \mathrm{O}$ (or $\mathrm{MeOH}-\mathrm{H}_{2} \mathrm{O}$ ) at a flow rate of $2 \mathrm{~mL} / \mathrm{min}$. ODS (12 nm-50 $\mathrm{m}$, YMC Co. Ltd., Kyoto, Japan), Sephadex LH-20 (Pharmacia, Uppsala, Sweden), as well as silica gel (100-200 and 300-400 mesh, Qingdao Marine Chemical plant, Qingdao, China) were utilized for column chromatography. Moreover, pre-coated silica gel $\mathrm{GF}_{254}$ plates (Zhi Fu Huang Wu Pilot Plant of Silica Gel Development, Yantai, China) were utilized for TLC $\left(\mathrm{CH}_{2} \mathrm{Cl}_{2}: \mathrm{MeOH} 100: 1\right)$, the spots on TLC were detected by spraying with $5 \% \mathrm{H}_{2} \mathrm{SO}_{4}$ in EtOH. All solvents utilized were of analytical grade (Beijing Chemical Works).

\subsection{Plant Material}

Agarwood which was induced by Agar-Wit from 7 years old A. sinensis tree was harvested about 18 months later, which was collected from Pingding Town, Huazhou City, Guangdong Province, China, in September 2014. The sample was identified by Prof. Jian-he Wei, Institute of Medicinal Plant Development, Chinese Academy of Medical Sciences and Peking Union Medical College, where a voucher specimen (No. 20140907) was deposited.

\subsection{Extraction and Isolation}

Dried and powdered Agarwood $(10 \mathrm{~kg})$ was also refluxed with 95\% EtOH $(50.0 \mathrm{~L} \times 3)$ within conditions of reflux in yielding a semi-solid residue $(850 \mathrm{~g})$ which was made of the crude extract. The crude extracts were then dissolved successively with water $(2 \mathrm{~L})$, in the order, petroleum ether (MSO), dichloromethane $\left(\mathrm{CH}_{2} \mathrm{Cl}_{2}\right)$, ethyl acetate (EtOAc) as well as $n$-butanol $(n \mathrm{BuOH})$, in re-extracting water solution of the crude extract as well as obtaining different fractions.

The $\mathrm{CH}_{2} \mathrm{Cl}_{2}$ extract (86.5 g) was applied to silica gel (100-200 mesh) chromatographic column then it successively eluted with $\mathrm{MSO}-\mathrm{CH}_{2} \mathrm{Cl}_{2}\left(v / v, 100: 0-1: 20,3.0 \mathrm{~L}\right.$ of each), $\mathrm{CH}_{2} \mathrm{Cl}_{2}-\mathrm{MeOH}(v / v$, 100:0-0:100, 3.0 L of each) in providing twenty fractions (Fr. 1-Fr. 20). Fr. 1-9 mix with Fr. 10 (Fr. A) (10.5 g) was subjected to silica gel (200-300 mesh) chromatographic column as well as eluted with MSO- $\mathrm{CH}_{2} \mathrm{Cl}_{2}\left(v / v, 10: 0-1: 1,0.5 \mathrm{~L}\right.$ of each), $\mathrm{CH}_{2} \mathrm{Cl}_{2}-\mathrm{MeOH}(v / v, 100: 0-0: 100,0.5 \mathrm{~L}$ of each) to get nine sub-fractions (Fr.A-1-Fr. A-9). Fr.A-3 (3.0 g) was subjected to further purified by semi-preparative liquid chromatography (LC) with $\mathrm{CH}_{3} \mathrm{CN}-\mathrm{H}_{2} \mathrm{O}(v / v, 6: 4)$ isolated to yield compound 1 (21.7 mg, $\left.t_{\mathrm{R}}=35.9 \mathrm{~min}\right)$.

Accordingly, the EtOAc extract (35.1 g) was also isolated to silica gel (100-200 mesh) chromatographic column and successively eluted with $\mathrm{CH}_{2} \mathrm{Cl}_{2}-\mathrm{MeOH}(v / v, 100: 0-0: 100,3.0 \mathrm{~L}$ of each) to give 7 fractions (Fr.A-Fr.G). Fr. A (8.1 g) was applied to silica gel (100-200 mesh) chromatographic column by eluted with MSO- $\mathrm{CH}_{2} \mathrm{Cl}_{2}$ (v/v, 1:1, 1:3, $1 \mathrm{~L}$ of each), $\mathrm{CH}_{2} \mathrm{Cl}_{2}-\mathrm{MeOH}$ (v/v, 100:0-0:100, 1.0 L of each) to provide six sub-fractions(Fr.A-1-Fr.A-6). Fr.A-3 (2.5 g) was chromatographed by ODS gel $(3 \times 40 \mathrm{~cm})$ eluted with $\mathrm{MeOH}-\mathrm{H}_{2} \mathrm{O}(v / v, 3: 7,1.0 \mathrm{~L}$ of each $)$ to increase polarity to give eight sub-fractions (Fr.A-3-1-Fr.A-3-8). Compound $2\left(7.3 \mathrm{mg}, t_{\mathrm{R}}=22.2 \mathrm{~min}\right)$ and $4\left(8.2 \mathrm{mg}, t_{\mathrm{R}}=18.1 \mathrm{~min}\right)$ were separated out from the mixture of Fr.A-3-4-18 29 by semi-preparative LC with $\mathrm{CH}_{3} \mathrm{CN}-\mathrm{H}_{2} \mathrm{O}$ $(v / v, 50: 50)$. Fr.A-3-2 (0.4 g) which was then purified by semi-preparative LC with $\mathrm{MeOH}-\mathrm{H}_{2} \mathrm{O}(v / v$, $44: 56)$ isocratic to produce compound $3\left(7.3 \mathrm{mg}, t_{\mathrm{R}}=32.7 \mathrm{~min}\right)$. 
The structures of compounds $\mathbf{1}-\mathbf{4}$ were determined by UV, IR, ${ }^{1} \mathrm{H}-\mathrm{NMR},{ }^{13} \mathrm{C}-\mathrm{NMR},{ }^{1} \mathrm{H}-{ }^{1} \mathrm{H}$ COSY, HSQC, HMBC, NOESY and HR-ESI-MS.

5-Hydroxy-7-methoxy-2-[2-(4'-methoxyphenyl)ethyl]chromone (1). $\mathrm{C}_{19} \mathrm{H}_{18} \mathrm{O}_{5}$, pale yellow amorphous powder; m.p. $185-187^{\circ} \mathrm{C}$; UV $\lambda_{\max }\left(\mathrm{CHCl}_{3}\right) \mathrm{nm}(\log \varepsilon): 225$ (4.14), 318 (3.66); IR (KBr) $\nu_{\max } \mathrm{cm}^{-1}$ : 1030, 1220, 1275, 1365, 1480, 1620, 3415; HR-ESI-MS m/z 349.1023 [M + Na] ${ }^{+}$(calcd. 349.1052); ${ }^{1} \mathrm{H}-\mathrm{NMR}$ spectra data, see Table $1 ;{ }^{13} \mathrm{C}-\mathrm{NMR}$ spectrum data, see Table 2.

5,8-Dihydroxy-6-methoxy-2-(2-phenylethyl)chromone (2). $\mathrm{C}_{18} \mathrm{H}_{16} \mathrm{O}_{5}$, pale yellow amorphous powder; m.p. 124-127 ${ }^{\circ} \mathrm{C}$; UV $\lambda_{\max }\left(\mathrm{CHCl}_{3}\right) \mathrm{nm}(\log \varepsilon): 242$ (4.6), 322 (4.15); IR (KBr) $v_{\max } \mathrm{cm}^{-1} 1512,1455,1610$, 3424; HR-ESI-MS $m / z 335.0902\left[\mathrm{M}+\mathrm{Na}^{+}\right.$(calcd for $\left.\mathrm{C}_{18} \mathrm{H}_{16} \mathrm{O}_{5} \mathrm{Na}, 335.0895\right) ;{ }^{1} \mathrm{H}-\mathrm{NMR}$ spectra data, see Table $1 ;{ }^{13} \mathrm{C}-\mathrm{NMR}$ spectrum data, see Table 2.

$5 \alpha, 6 \alpha$-Epoxy-7 $\beta, 8 \alpha, 3^{\prime}$-trihydroxy-4'-methoxy-2-(2-phenylethyl)chromone (3). $\mathrm{C}_{18} \mathrm{H}_{18} \mathrm{O}_{7}$, pale brown amorphous powder, $[\alpha]_{\mathrm{D}}^{20}-12.5(c 0.10, \mathrm{MeOH}) ; \mathrm{UV} \lambda_{\max }(\mathrm{MeOH}) \mathrm{nm}(\log \varepsilon): 254$ (4.02), 205 (4.45); IR (KBr) $v_{\max } \mathrm{cm}^{-1} 3410,3010,1660,1610,1500,1425,1265,1240,1120,1100,1015$; HR-ESI-MS at $m / z$ $371.1103[\mathrm{M}+\mathrm{Na}]^{+}$(calcd for $\left.\mathrm{C}_{18} \mathrm{H}_{18} \mathrm{O}_{7} \mathrm{Na}, 371.1107\right) ;{ }^{1} \mathrm{H}-\mathrm{NMR}$ spectra data, see Table $1 ;{ }^{13} \mathrm{C}-\mathrm{NMR}$ spectrum data, see Table 2.

6-Methoxy-2-[2-(2',3', 4'-trihydroxy)phenyl)ethyl]chromone (4). $\mathrm{C}_{18} \mathrm{H}_{16} \mathrm{O}_{6}$, pale brown amorphous powder; UV $\lambda_{\max }(\mathrm{MeOH}) \mathrm{nm}(\log \varepsilon): 242$ (4.56), 340 (3.75); IR (KBr) $\nu_{\max } \mathrm{cm}^{-1} 3340,2545,1610,1512,1405$, 1310, 1284, 1140, 1020; HR-ESI-MS $\left(m / z 351.0821[\mathrm{M}+\mathrm{Na}]^{+}\right.$, calc. for $\mathrm{C}_{18} \mathrm{H}_{16} \mathrm{O}_{6} \mathrm{Na}$, 351.0845); ${ }^{1} \mathrm{H}-\mathrm{NMR}$ spectra data, see Table $1 ;{ }^{13} \mathrm{C}-\mathrm{NMR}$ spectrum data, see Table 2.

\subsection{Assay for Inhibitory Ability Against LPS-Induced NO Production in RAW 264.7 Macrophages}

The in vitro anti-inflammatory activity was assessed through determining the nitrite concentration in the medium as well as the proliferation of RAW264.7 cells as illustrated in a previous study with some modify $[10,11]$. Shortly, the cells $\left(10^{5}\right.$ cells/well) were co-incubated with drugs (Compounds 1-4 and Aminoguanidine) as well as LPS $(1 \mu \mathrm{g} / \mathrm{mL})$ for $24 \mathrm{~h}$ at $37^{\circ} \mathrm{C}$. The tested samples were dissolved in DMSO, and then diluted with DMEM to make the final DMSO concentration of $0.1 \%$. After that, the cells were coincubated with fresh medium $(150 \mu \mathrm{L} /$ well $)$ and then treated with LPS $(200 \mathrm{ng} / \mathrm{mL})$, and the tested compounds at various concentrations $(0.2-50.0 \mu \mathrm{M})$ for $24 \mathrm{~h}$. Griess reagent was used to determine the NO production by detecting the nitrite in the culture supernatant. In short, $100 \mu \mathrm{L}$ of the culture supernatant was reacted with an equal volume of Griess reagent and vibrated for $10 \mathrm{~min}$ at room temperature. The amount of $\mathrm{NO}$ was assessed by finding the nitrite concentration in the cultured RAW 264.7 macrophage supernatants with Griess reagent. Aliquots of supernatants $(100 \mu \mathrm{L})$ were also incubated, in-sequence, with $50 \mu \mathrm{L}$ of $1 \%$ sulfanilamide and $50 \mu \mathrm{L}$ of $0.1 \%$ naphthylethylenediamine in $2.5 \%$ phosphoric acid solution. From this, the absorbance was recorded on a micro-plate reader at a wavelength of $570 \mathrm{~nm}$. The results were expressed as $\mathrm{IC}_{50}$ values which were calculated using the CalcuSyn program and expressed as the means with SD of three independent experiments.

Supplementary Materials: The following are available online at: http://www.mdpi.com/1420-3049/21/11/ 1433/s1. The NMR (1D and 2D) of compounds 1-4 are available as Supplementary Materials.

Acknowledgments: This work was supported by the National Natural Science Foundation of China (No. 81403055 and 81303312) and Science \& Technology Programs from Hainan Province of China (No. ZDKJ2016004).

Author Contributions: Y.-Y. Liu wrote the paper and prepared the manuscript. Y.-Y. Liu, D.-L. Chen and W. Zheng performed the isolation, structure elucidation of the constituents. J. Feng and Z. Zhang conducted the bioassay experiments and analyzed data. Y.Y. Liu and Y. Yang collected the agarwood material. The whole research was performed based on the planning of J.-H. Wei. The authors read and approved the final manuscript.

Conflicts of Interest: The authors have declared no conflict of interest. 


\section{References}

1. Li, W.; Cai, C.H.; Dong, W.H.; Guo, Z.K.; Wang, H.; Mei, W.L. 2-(2-Phenylethyl)chromone derivatives from Chinese agarwood induced by artificial holing. Fitoterapia 2014, 98, 117-123. [CrossRef] [PubMed]

2. Liu, Y.Y.; Chen, H.Q.; Yang, Y.; Zhang, Z.; Wei, J.H.; Meng, H.; Chen, W.P.; Feng, J.D.; Gan, B.C.; Chen, X.Y.; et al. Whole-tree agarwood-inducing technique: An efficient novel technique for producing high-quality agarwood in cultivated Aquilaria sinensis trees. Molecules 2013, 18, 3086-3106. [CrossRef] [PubMed]

3. Yang, D.L.; Wang, H.; Guo, Z.K.; Dong, W.H.; Mei, W.L.; Dai, H.F. A new 2-(2-phenylethyl)chromone derivative in Chinese agarwood 'Qi-Nan' from Aquilaria sinensis. J. Asian Nat. Prod. Res. 2014, 7, 770-776. [CrossRef] [PubMed]

4. Zhang, X.L.; Liu, Y.Y.; Wei, J.H.; Yang, Y.; Zhang, Z.; Huang, J.Q.; Chen, H.Q.; Liu, Y.J. Production of high-quality agarwood in Aquilaria sinensis trees via whole-tree agarwood-induction technology. Chin. Chem. Lett. 2012, 23, 727-730. [CrossRef]

5. Wei, J.H.; Yang, Y.; Zhang, Z.; Meng, H.; Feng, J.D.; Gan, B.C. Infusion Set for Producing Agarwood and Production Method of Agarwood. CN101755629A, 1 January 2010.

6. Wei, J.H.; Zhang, Z.; Yang, Y.; Meng, H.; Gao, Z.H.; Xu, Y.H.; Zhang, X.L.; Liu, Y.Y.; Chen, X.Y.; Chen, W.P.; et al. Infusion Set for Producing Agarwood and Production Method of Agarwood. PCT/CN2012/071599, 24 February 2012.

7. Naef, R. The volatile and semi-volatile constituents of agarwood, the infected heartwood of Aquilaria species: A review. Flavour Fragr. J. 2011, 26, 73-87. [CrossRef]

8. Toru, Y.; Naomi, S.; Michiho, I.; Fumiyuki, K.; Gisho, H. Three novel diepoxy tetrahydrochromones from agarwood artificially produced by intentional wounding. Tetrahedron Lett. 2005, 46, 4395-4398.

9. Wu, B.; Kwon, S.W.; Hwang, G.S.; Park, J.H. Eight new 2-(2-phenylethyl)chromone (=2-(2-phenylethyl)-4H1-benzopyran-4-one) derivatives from Aquilaria malaccensis Agarwood. Helv. Chim. Acta 2012, 95, 1657-1665. [CrossRef]

10. Huang, X.J.; Tang, J.Q.; Li, M.M.; Liu, Q.; Li, Y.L.; Fan, C.L.; Pei, H.; Zhao, H.N.; Wang, Y.; Ye, W.C. Triterpenoid saponins from the rhizomes of Anemone flaccida and their inhibitory activities on LPS-induced NO production in macrophage RAW264.7 cells. J. Asian Nat. Prod. Res. 2014, 9, 910-921. [CrossRef] [PubMed]

11. Ma, G.X.; Zhang, X.P.; Li, P.F.; Sun, Z.H.; Zhu, N.L.; Zhu, Y.D.; Yang, J.S.; Chen, D.L.; Wu, H.F.; Xu, X.D. Four new phenolic acid with unusual bicycle [2.2.2] octane moiety from Clerodendranthus spicatus and their anti-inflammatory activity. Fitoterapia 2015, 105, 61-65. [CrossRef] [PubMed]

Sample Availability: Samples of the compounds and agarwood are available from the authors.

(C) 2016 by the authors; licensee MDPI, Basel, Switzerland. This article is an open access article distributed under the terms and conditions of the Creative Commons Attribution (CC-BY) license (http://creativecommons.org/licenses/by/4.0/). 